\title{
Strategic Studies in Britain and the Cold War's Last Decade ${ }^{1}$
}

\author{
Lawrence Freedman
}

For decades, from 1982, Bob O'Neill played a central role in the British strategic studies community, first as Director of the International Institute for Strategic Studies (IISS) and then as Chichele Professor of the History of War at Oxford. He also served, usually as chair, on the boards of numerous other organisations, including IISS, the Imperial War Museum, and the Centre for Defence Studies at King's College. I have described elsewhere the remarkable qualities Bob brought to any organisation in which he had a part to play, and his unique talent for leadership:

Bob was always in control and always polite, though occasional signs of irritation were allowed to intrude in the face of specious arguments or when time was being wasted with mini-speeches. Potential objections were anticipated and parochial concerns deflected. He was particularly effective at making an organisation feel good about itself and its staff pleased with a job well done. At the same time, while sustaining morale and boosting the public profile, he would never allow an organisation to go into denial and put off addressing its problems. About these problems, whether to do with personnel or finance, he would stay well informed. Part of Bob's success was his

1 Thanks to Jeff Michaels for his comments. 
ability to develop rounded assessments of the people he was working with, even to junior levels, aware of their strengths as well as their weaknesses and the links between the two. ${ }^{2}$

This leadership was of particular importance at a time when the established framework for thinking about security was undermined, and then set aside. This period started with the Cold War, edging towards a new and dangerous peak. Then not only did the sense of danger start to subside, but the Cold War itself came to an abrupt, although fortunately rather graceful, conclusion. This was followed by a whole series of new issues bursting on to the agenda, courtesy of Saddam Hussein, Slobodan Milosevic, and then Osama bin Laden. Leadership in these circumstances required steadiness, so that people did not get giddy with the pace of change, yet crucially it also depended on appreciating the possibilities and the challenges in the new situation.

My aim in this chapter is to convey the state of the strategic studies community in Britain as Bob $\mathrm{O}^{\prime}$ Neill arrived to take up his role as Director of IISS, with some observations about how it changed over the subsequent decade. This community was, and still is, made up of the defence specialists and students of international relations in universities and think tanks. Bob's arrival at IISS was coincident with my own at King's College London as Professor of War Studies, and for much of this period I was on the Council of IISS. This chapter therefore inevitably reflects my perspective as both an observer and a participant.

\section{I}

At the start of the 1980s, many of the most influential figures in the defence debate were retired military officers with distinguished war records. Field Marshal Lord Carver, a former Chief of Defence Staff, was regularly cited as a critic of nuclear policy. ${ }^{3}$ General Sir John Hackett's fictional account of The Third World War (which NATO just won) was a bestselling vehicle for making the case for higher defence

2 Freedman, Lawrence (2006) 'Bob O'Neill and the Art of Academic Leadership', Australian Journal of International Affairs 60(1), pp. 13-17.

3 Carver, Michael (1982) A Policy for Peace, London: Faber. 
spending. ${ }^{4}$ Meanwhile, the number of academic specialists in defence and strategy was small. The overseas priorities of universities had been shaped by the demands of empire more than the threat of war. They provided for those with the administrative competence and language skills to run the colonies. In many university departments there were scholars who had spent time in Africa and Asia and had picked up on their languages and cultures. By contrast, chairs - never mind whole departments - dedicated to war were rare. Standing out was the Chichele Chair of the History of War at Oxford, occupied by Sir Michael Howard in 1980. His appointment as Regius Professor of History left the post unfilled until it was taken up by Bob O'Neill in 1987. Howard had also established the other chair with war in its title while at King's College London. Aware of the college's unsatisfactory foray into military studies during the interwar years, he created the War Studies Department during the 1950s and became its first chair in 1965. Shortly after, it was Howard who after persuaded Defence Secretary Denis Healey to get the Ministry of Defence to sponsor a number of academic posts in this field. This program continued through the 1980s, effectively coming to an end with the seed funding for the Centre for Defence Studies at King's College (in collaboration with the London School of Economics and Political Science (LSE)) in $1990 .^{5}$

By the early 1980s, there were centres of excellence around the country in particular areas, including defence economics at Aberdeen, arms control at Lancaster, and Soviet studies at Birmingham. At Edinburgh, John Erickson had established himself as a leading interpreter of Soviet military history and thought. ${ }^{6}$ Looking back, it is striking how little academic work was under way on the conduct, as opposed to the politics, of the conflict which had taken British lives and consumed much governmental energy - 'the Troubles' (a typical British euphemism) in Northern Ireland. The field of terrorism studies, now a more crowded field, was dominated by Paul Wilkinson, then at Aberdeen before he later set up a centre at St Andrews. ${ }^{7}$

4 The Third World War, London: Sidgwick \& Jackson, was first published in 1978 and then in an updated version in 1982.

5 On the background, see Howard, Michael (2006) Captain Professor: The Memoirs of Sir Michael Howard, London: Continuum International Publishing Group, p. 195.

6 The Guardian (2002) 'Humanities: John Erickson'. Available at: www.theguardian.com/ news/2002/feb/12/guardianobituaries.humanities.

7 Wilkinson, Paul (1977) Terrorism and the Liberal State, London: John Wiley. 
The Department of War Studies at King's was then still small, with Barrie Paskins, a defence lecturer on the ethics of war, with three other colleagues. ${ }^{8}$ When Howard had become the first defence lecturer at All Souls in Oxford in 1968, the Chair of War Studies he had created was filled by Laurence Martin. It became vacant when Martin left to become Vice Chancellor of Newcastle University in 1978. It was revived in 1982 as the personal project of Air Marshal Sir Neil Cameron when he became principal of the college. That is how I came to move from the Royal Institute of International Affairs, better known as Chatham House, to King's.

King's also had a link with the Royal Naval College Greenwich, the only staff college to have a dedicated academic department. The Department of History and International Affairs had been led by Brian Ranft, who had a part-time position at King's when I arrived. He was followed in this position by Peter Nailor. One of Nailor's colleagues, Geoff Till, a former King's student, took up the part-time position when Ranft retired to ensure that maritime studies were on the curriculum (a role later taken up by Andrew Lambert). Till succeeded Nailor at Greenwich in 1989 and then became one of the main architects of the academic support function at the new Joint Services Command and Staff College, which merged all three staff colleges in the late 1990s. With King's now responsible for this function, Till became a full Professor at King's, and the first Dean of Defence Studies. Up to this point, there was little internal academic support at the other staff colleges. Brian Holden Reid was seconded from King's to the Army Staff College at Camberley, where he was resident historian from 1987 to 1997. The army did have substantial departments at the Royal Military College at Sandhurst, teaching cadets. Its staff included the leading military historian John Keegan, until he left to join the Daily Telegraph in 1986. Another member of the Sandhurst staff, Chris Donnelly, was the leading expert on the Soviet military system. ${ }^{9}$ The naval equivalent at Dartmouth also had a strong teaching staff, including the naval historian Eric Grove. Meanwhile, the RAF relied

8 Michael Dockrill, Brian Bond, and Wolf Mendl.

9 Donnelly's influence was considerable. In 1979, he became head of the Soviet Studies Research Centre, also based at Sandhurst, and in 1989 became an adviser to the NATO SecretaryGeneral, helping to manage the aftermath of the end of the Cold War. 
on a series of impressive officers, starting with Tony Mason in 1976 and later including Andrew Vallance and Tim Garden, who developed links with the universities.

While the specialist defence community was small, the wider international relations community was growing and starting to organise itself as a discipline. The first conference of the British International Studies Association was held in 1975 at Lincoln College Oxford under the Chairmanship of Alastair Buchan, then at Oxford but also the founding director of IISS. The very first Department of International Relations had been created at Aberystwyth after the First World War. The Montague Burton Chairs at Oxford and the LSE, established in the 1930s, were accepted as the leading chairs in the profession. The Australian Hedley Bull took over the Oxford chair from Buchan after the latter's untimely death in 1978, only to himself die distressingly young from cancer in $1985 .{ }^{10}$ At LSE, Philip Windsor, another IISS alumnus, led on security studies, while the Montague Burton Professor, Susan Strange, was creating a new field of internal political economy, moving the subject away from its preoccupation with states and security. Elsewhere, Joseph Frankel had built up a formidable department at Southampton, from which a remarkable number of later stars emerged, including Steve Smith.

Outside of academia, the think tank world was small but high powered. Chatham House was another product of the aftermath of the First World War. It had been set up to help avoid another major war. Under the economist Andrew Shonfield, it had broken its focus. Ian Smart, a former Foreign and Commonwealth Office (FCO) official who had been at IISS before becoming Shonfield's deputy, was one of the most original and articulate commentators on security issues during the 1970s. He set up a project on the future of British foreign policy, for which I was recruited, and then wrote the project's most important paper, a study of the options for Polaris replacement. ${ }^{11}$ He could have become director, but instead became a consultant on nuclear energy matters, and dropped away from the defence world. Instead, journalist David Watt, who was well connected and a brilliant writer, but did not claim any specialist expertise, became the new director.

10 Ayson, Robert (2012) Hedley Bull and the Accommodation of Power, London: Palgrave.

11 Smart, Ian (1997) The Future of the British Nuclear Deterrent: Technical, Economic, and Strategic Issues, London: Royal Institute of International Affairs. 
IISS had been established in the first place as a result of concern in the 1950s that defence policy in the nuclear age required a degree of specialist knowledge that was beyond existing institutions. Its international reputation was based on published output, notably the Military Balance and the Adelphi Papers, while its annual conference was the most important gathering of its kind, including senior figures from many governments and international organisations, as well as academics and think tank members. The directing staff comprised of a non-British director (Christoph Bertram of Germany, and then Bob) and a British deputy with an army background (Brigadier Kenneth Hunt, followed by Colonel Jonathan Alford), supplemented by a series of up and coming young Americans (in the first years of the 1980s this was Bob Nurick) and an international group of largely young research associates. It was an incubator for new faces in the transatlantic strategic studies community. In the early 1980s, it moved from its spartan accommodation in John Adam Street to smart new premises in Tavistock Street, close to both LSE and King's. It was also, once an endowment from the Ford Foundation was agreed, on a more secure financial footing than Chatham House, which, unlike its European interlocutors, did not get a large government subsidy. ${ }^{12}$

The other member of the London think tank triumvirate was the Royal United Services Institute (RUSI). It also lived on a tight budget, in this case with life support from the Ministry of Defence. In principle, it was the main outlet for military voices. In the 1970s, these had often been quite right-wing, especially under the strident leadership of Air Marshal Stuart 'Paddy' Menaul, who remained an active commentator on defence matters. ${ }^{13}$ By 1982, the institute had returned to the more measured tones of the establishment, and was directed by another airman, Group Captain David Bolton. Other London think tanks, such as the Institute for the Study of Conflict,

12 From 1978 to 1982 , I ran a small policy studies unit that did get a modest grant from the FCO.

13 Towards the end of his reign at the RUSI it was perceived that a less individualistic and a more collegiate approach was appropriate, and in 1976 he left to continue his work as publicist and defence commentator. Air Vice-Marshal SWB Menaul CB CBE DFC AFC (1987) ‘RUSI DirectorGeneral 1968-1976: An Appreciation', The RUSI Journal 132(3), pp. 25-6. 
provided a focus for strong anti-communist views, ${ }^{14}$ but these were quite small and considered more as a source of strong opinions than independent analysis.

How influential were the think tanks? At the time I was not sure, as I suggested in a seminar on the role of the outsiders in policy-making at RUSI at the end of $1981 . .^{15}$ My experience working at Chatham House during the late 1970s was that government was resistant to outside influences. This included parliament as well as academics and think tank members. On the nuclear issue, for example, there had been minimal parliamentary activity since 1965 . Civil servants were prohibited from participating in the Chatham House study group that led to the production of Ian Smart's paper on the Polaris replacement. Even in small private gatherings put together under the aegis of one of the institutes, and despite the latitude made possible by invoking the Chatham House Rule, ${ }^{16}$ the burden of official secrecy and political caution weighed heavily.

Having done my doctoral research on the United States, I was always struck by the ease with which I could get hold of information in Washington that would get the highest classification in the UK, as well as the ease of movement between the government and think tank worlds. In Washington, individuals with real expertise had a reasonable expectation of getting a spell in government and returning to the think tank world, at which point they could enrich public debate with their knowledge of the workings of government. Other than temporary appointments to the FCO's Planning Staff or Arms Control Unit, this was rare in the UK. Beyond that, the resources available to institutions such as RAND, to take the most famous American example, dwarfed those available to the British think tanks. They could not even aspire to undertake the sustained number-crunching that made them an adjunct to policy-making, or grow large on the basis of government

14 Michaels, Jeff (2014) 'Britain's Cold War Think Tank: Brian Crozier and the Institute for the Study of Conflict', in Luc van Dongen, Stéphanie Roulin and Giles Scott-Smith (eds), Transnational Anti-Communism and the Cold War: Agents, Activities, and Networks, London: Palgrave Macmillan.

15 Report of the Tripartite Seminar held at RUSI on 'Outsiders' Influence on Defence Policy: Part I', 11 November 1981; (1982) RUSI Journal 127(1).

16 'When a meeting, or part thereof, is held under the Chatham House Rule, participants are free to use the information received, but neither the identity nor the affiliation of the speaker(s), nor that of any other participant, may be revealed.' Chatham House, 'Chatham House Rule'. Available at: www.chathamhouse.org/about/chatham-house-rule\#sthash.nzqXyGcB.0TSMHZAl.dpuf. 
contracts. I recall being told by a Conservative MP when I was trying to arrange a briefing on the Polaris report that our efforts were paltry and pointless. We could never compete with RAND.

It is also important to keep in mind that all three institutes were membership organisations, who had to spend a lot of time providing a steady diet of speakers and seminars, as well as highquality publications. IISS's Military Balance, for example, provided authoritative information on the state of the world's armed forces. Chatham House had also played a long role in recording developments in foreign policy as much as seeking to influence its conduct. In both Chatham House and IISS, the libraries were of immense importance, especially when it came to press cuttings. In the pre-Google age, these were the first port of call for anyone trying to study contemporary affairs. Researchers could not simply sit in their offices and find whatever information they wanted online, but had to go out and look for what they needed, armed with a note pad and, with luck, access to a decent photocopier.

In addition to their value as a safe arena for some interaction between independent researchers and policy-makers, the think tanks also offered international networks. IISS and Chatham House were linked not only to the main American centres, such as RAND and Brookings, but also the European institutes, such as the German Council on Foreign Relations, the German Institute for International and Security Affairs, and the French Institute for International Relations. The regular visits to London by individuals such as Karl Kaiser and Uwe Nehrlich from Germany, Thierry de Montbrial and Pierre Hassner from France, and Johann Jørgen Holst from Norway (later to become Norwegian Foreign Minister) brought a wider European perspective to UK debates on security. As I will discuss presently, there were also reasonably regular links with the foreign policy institutes in the Soviet Union and the Warsaw Pact.

II

By the early 1980s, the academic and policy debate was contained within the Cold War framework, which in itself carried the legacy of the terrible history of the twentieth century. It was a field of study originally animated by the problem of war. That meant exploring 
how relations between states went wrong. The academic study of international relations tended towards a commentary on the great powers that was both historically informed and sensitive to recent developments. The practitioners might express strong views, but their backgrounds were not dissimilar to other members of the establishment, and the tradition was donnish. While few academics entered government, there was movement in the other direction for example, Peter Nailor had moved from the Ministry of Defence to take up a chair at Lancaster. The vocation was to pass on learning to the next generation while writing about topics of interest when in the mood to do so. Journalism was largely frowned upon as being somehow demeaning, although book reviewing was considered a high art. Although money was tight, university life was far less pressured. This was before the start of the successive research assessment exercises.

A shared feature of the senior figures in government and academia was the impact of their wartime experiences and the early stages of the Cold War on their world views. This was a generation that was, by the early 1980s, weary. They had lived through the country's heroic stand against Hitler and a time when British's international standing had not been in question. Many were still dogged by Dean Acheson's 1962 jibe about Britain having lost an empire and failed to find a role. ${ }^{17}$ Dependence on the United States for security and influence was understood but resented, often manifesting itself in a distrust of the latest American intellectual fashion. Above all, there was a dismayed sense that the relative decline that the country had known since 1945, which had seen former enemies overtake Britain in prosperity, was bound to continue.

If there was a dominant disciplinary influence, it was history, with the more ambitious using familiar concepts to explore the different ways of thinking about the developing international system. ${ }^{18}$ The so-called English school, which was only given its name in $1981,{ }^{19}$ was initially associated with Martin Wight, who had died in 1972.

17 Speech at West Point, 5 December 1962, in Vital Speeches, 1 January 1963, p. 163. On the consequences, see Hill, Christopher (1979) 'Britain's Elusive Role in World Politics', British Journal of International Studies 5(3), pp. 248-59.

18 For example, Frankel, Joseph (1970) National Interest, London: Macmillan.

19 By Roy Jones in (1981) 'The English School of International Relations: A Case for Closure', The Review of International Studies 7(1), pp. 1-13. 
It reflected the idea that the international system could be viewed as a society with its own norms and conventions, and not just as a collection of autonomous states. ${ }^{20}$ In some ways, it was less a school of thought than an intellectual temper, offering a somewhat pragmatic middle way between more dogmatic realists and idealists. It was not offering a radical new way of looking at international affairs.

The durability of the established frameworks was evident when it came to the analytical support for the critics of mainstream views. The idealist strand in British thinking about international affairs was sustained largely by two academic outfits, initially with a Quaker inspiration. The Richardson Institute for Peace Research, named after Lewis Fry Richardson, was established in 1959. It first found a home at Lancaster University and eventually went to Kent, where it became part of the Conflict Research Centre. Until 1982, its director was Michael Nicholson, who very much followed Richardson in his belief that quantitative analysis could be used to put the study of war and peace on a more scientific basis. In many ways, Nicholson, who had a background in economics, was a rare and early representative in Britain of the scientific approach that was gradually gaining traction in the United States. ${ }^{21}$ The other component to what became the Conflict Research Centre was the more idiosyncratic work of John Burton, first at University College London from 1963 and then at Kent. Burton, who had been a senior member of the Australian Foreign Office, believed that a more holistic view of the world, and a sustained focus on basic human needs, could be the basis for new techniques of conflict resolution. ${ }^{22}$

20 The classic text is normally now seen to be Butterfield, Herbert and Martin Wight (eds) (1966) Diplomatic Investigations: Essays in the Theory of International Politics, London: Allen \& Unwin. See Dunne, Tim (1998) Inventing International Society: A History of the English School, Basingstoke: Macmillan; Linklater, Andrew and Hidemi Suganami (2006) The English School of International Relations: A Contemporary Reassessment, Cambridge: Cambridge University Press.

21 Nicholson, Michael (1989) Formal Theories in International Relations, Cambridge: Cambridge University Press; The Guardian (2001) 'Social Sciences: Michael Nicholson'. Available at: www. theguardian.com/news/2001/oct/20/guardianobituaries. socialsciences.

22 Burton, John (1979) Deviance, Terrorism and War, London: Macmillan; The Guardian (2010) 'John Burton Obituary'. Available at: www.theguardian.com/world/2010/aug/22/john-burtonobituary. 
The main centre of peace research was the Department of Peace Studies at Bradford University, founded by Quakers in 1973, with Adam Curle as the first chair. It barely survived its first few years. It was caught between its original Quaker inspiration and radicals who believed that there could be no peace without justice, and that justice could require armed struggle, and also between those who believed that the cause of peace could best be advanced through scholarship, and those who believed that their scholarship was secondary to activism. ${ }^{23}$ The problem was aggravated by Curle's relaxed approach to the demands of academic life. In 1978, Curle retired and was replaced by a tough-minded former missionary, James O'Connell, who restored discipline and stressed the importance of scholarship. Without O'Connell, it is likely that the department would have survived, either because of its internal tensions or because of the hostility of the Thatcher Government, which took the view that this was not so much peace as appeasement studies. The government demanded that the University Grants Commission investigate Bradford to assess whether this could possibly be a serious academic department - it was. ${ }^{24}$ From Bradford, Paul Rogers was to the fore with the most sustained critique of British and NATO nuclear policy.

The King's Department of War Studies and Bradford's Department of Peace Studies were often set against each other, as if they were polar opposites. The Department of War Studies was not activist, and contained a range of views. Wolf Mendl, the head of department up to my arrival, was a Quaker who shared O'Connell's combination of strong values and deep commitment to rigorous scholarship. Moreover, to the extent that nuclear deterrence was at issue, there were a number of common reference points. Supporters of deterrence were not arguing in favour of nuclear war. The issue was how best to prevent one. Nor were the critics opposed to the measures of arms control that helped stabilise rather than eliminate the nuclear relationship.

Indeed, arms control was the focal point for younger scholars with an interest in what might now be called 'hard power'. The British International Studies Association arms control group was led (with some help from me) by John Simpson at Southampton, already

\footnotetext{
23 Young, Nigel (1981) 'Educating the Peace Educators', Security Dialogue 12(2), pp. 123-35.

24 The Guardian (2013) 'James O'Connell Obituary'. Available at: www.theguardian.com/ education/2013/sep/19/james-oconnell-academic-dies-87.
} 
a leading expert in the non-proliferation field. The focus was telling. The intellectual challenge was to be found in managing the arms race and east-west relations. This was not a group that entered the arena to talk about war, but more to consider how it might best be prevented. The vital knowledge was of the properties of nuclear weapons and the doctrines of strategic stability, the coherence of alliances and the conventions of crisis management. There was little reason to talk of the conduct of war itself, because if the one for which we were most prepared came about, this would constitute a monumental failure of policy and a catastrophe from which there might be no recovery.

III

The sense of decline was reflected in the wider public debates on foreign and defence policy. These were still influenced as much by the logic of decolonisation as by the ebb and flow of the Cold War. In the late 1960s, the contraction of the empire led the Labour Government to conclude that it was pointless to sustain military garrisons in the Middle East and the Far East. It appeared that the country no longer had vital interests beyond Europe worth defending by force of arms. The sovereign base area in Akrotiri and Dhekelia would have been handed over to the government in Cyprus were it not for the awkward situation arising out of the 1974 Turkish invasion of Cyprus and the island's partition. The relentlessly narrow focus on the NATO area was confirmed in 1981 by the defence review undertaken by Sir John Nott, much to the chagrin of the Royal Navy. This also removed the last attempt at a maritime presence in the South Atlantic, HMS Endurance.

The review reflected a prominent theme of the defence debates of the 1970s, in which Professor David Greenwood at the University of Aberdeen had taken such a prominent role. Looking at the persistent pressure on the defence budget, struggling to stay close to the NATO norm of 3 per cent of GDP (and with a struggling GDP), he had pointed to the need to make hard choices on defence priorities, which were reflected in what seemed to be the core missions for the individual services - a long-range strike role for the RAF, sustaining the British Army of the Rhine, or the Royal Navy's surface fleet. The 1981 review came down against an expansive maritime presence, although this was, to a degree, to make way for a role on which the Royal Navy was 
less keen - responsibility for the national nuclear force. ${ }^{25}$ In 1980 , the government decided to replace the ageing SSBN force with Polaris missiles, with one carrying new US Trident missiles. ${ }^{26}$

This decision became bound up with the question of whether Britain had really come to terms with its reduced role in world affairs, as if Trident was a last defiant gesture in the long retreat from the glories of empire. It was also caught up with the revival of an anti-nuclear movement in the United Kingdom. At issue here was not only the national nuclear force but also the decision taken by the alliance to locate US ground-launched cruise missiles at Greenham Common and Molesworth bases in the UK, along with other European countries. ${ }^{27}$ With President Ronald Reagan's hawkish administration and the Soviet invasion of Afghanistan raising international tensions, the nuclear issue soon dominated public debate. It had an immediate impact on the Labour Party in opposition, with Michael Foot, a longtime supporter of the Campaign for Nuclear Disarmament, now leader. This, along with the party's general antipathy towards NATO and the EU, was one reason for a number of key figures leaving Labour and starting the new Social Democrat Party. ${ }^{28}$

Although Margaret Thatcher's Conservative Government is credited with turning around Britain's economic position and international standing during the 1980s, neither would have been predicted at the start of the decade, when the economic policies pursued by her government appeared to have worsened the position. 1982 was a transitional year. By March the economy had begun to recover and with it the Conservative Party's position in the opinion polls. Then in April came the Falklands War. This came out of the blue, with a British task force sent to defend a territory few could locate on a map

25 For his study of the Nott Review, see Greenwood, David (1981) Reshaping Britain's Defences, Aberdeen Studies in Defence Economics, no. 19.

26 For a flavour of the debates on nuclear weapons leading to this decision, see Freedman, Lawrence (1980) Britain and Nuclear Weapons, London: Macmillan.

27 The key text for the movement was Thompson, Edward and Dan Smith (1980) Protest and Survive, London: Penguin. Thompson was a radical historian. Dan Smith had worked for the Campaign for Nuclear Disarmament and then at the Richardson Institute. The title was a play on the government's civil defence pamphlet, Protect and Survive, published in May 1980.

28 Some of the ideas that influenced Social Democrat Party defence policy are found in Segal, Gerald et al. (1983) Nuclear War and Nuclear Peace, London: Macmillan. 
or knew was still owned by Britain. As surprising as the outbreak of war was, the task force was able to set sail quickly and was able to defeat Argentine forces decisively.

The Falklands raised issues about the conduct and utility of war well below the nuclear threshold, but neither the academic/think tank community nor the political class was geared to these issues. ${ }^{29}$ Although important debates about conventional strategy were underway in the United States at the time, and despite Field Marshal Sir Nigel Bagnall's long campaign to introduce new operational concepts into the British army, ${ }^{30}$ this was an area that civilian academics were largely content to leave to military practitioners. In practice, it was the nuclear debate, much more than the Falklands, that stirred up the British strategic studies community. Up to this point, the British line was to accept the idea that the nuclear age had turned out to be more stable than many had dared to hope. If there was a challenge it came from the 'neo-cons', a term already in use to describe the hard-line Democrats in the US who were dismayed at their party's soft line on the Soviet Union. Now the challenge came from the anti-nuclear movement. Their critique was not just of the policies of government, but of the craven intellectuals (such as me) who had turned into cheerleaders for deterrence. ${ }^{31}$ Yet this was still largely a new twist to an established debate. It did not really push out the boundaries.

\section{IV}

Ten years later, the strategic studies community in Britain looked very different. It was much larger and more varied in its interests and concerns. Most of this can be put down to the end of the Cold War and the emergence of new - or re-emergence of old - types of conflicts,

29 The media commentators during the campaign were invariably retired officers. See Adams, Valerie (1986) The Media and the Falklands Campaign, London: Macmillan.

30 See Shamir, Eitan (2011) Transforming Command: The Pursuit of Mission Command in the U.S., British and Israeli Armies, Stanford: Stanford University Press, chapter 5. Those working closely with the military, such as Brian Holden Reid and Christopher Donnelly (who illuminated Soviet doctrine), were among the exceptions. Among specialists, Richard Simpkins, a retired army officer, was influential. See his (1985) Race to the Swift: Thoughts on Twenty-First Century Warfare, London: Brassey's Defence Publishers.

31 I noted my alarm that 'however liberal I might be when compared with American Hawks, I was quite reactionary when compared with European doves', in the introduction to Freedman, Lawrence (1986) The Price of Peace: Living with the Nuclear Dilemma, New York: Henry Holt, p. 13. 
especially in the Balkans. Before addressing this major transformation in the international system, it is worth noting three other factors that influenced the community during the course of the 1980s.

The first was a more sceptical and searching approach in the media and in parliament. On the nuclear side, this was also helped by the readiness of the Conservative Government to defend their views on nuclear deterrence. Thus the Trident decision was accompanied in 1980 by an 'Open Government' document which laid out the rationale, and the program itself was subjected to an annual report by the Select Committee on Defence. ${ }^{32}$ The confidence with which the case was made reflected the role of Michael Quinlan, the key figure in the Ministry of Defence, who had also been one of the prime movers behind the NATO decisions on cruise missiles. ${ }^{33}$ There was also support for more analytical approaches to these and other policy issues in the flagship current affairs program Weekend World, hosted by Brian Walden, which drew on academic support as talking heads. ${ }^{34}$

The second factor was the growth of international relations as a popular discipline in its own right. At the start of the 1980s, higher education was squeezed hard by the government, and funding remained tight until late in the decade when Kenneth Baker, as Secretary of State for Education, called for an expansion of student numbers. This led to a rapid surge in student places over the next few years, as well as a number of former polytechnics acquiring university status. Strategic studies and international relations were beneficiaries of this surge. To take the example of King's, it was able to move from a niche master's degree to offer undergraduate courses in war studies, which in turn allowed it to expand the range of master's degrees. ${ }^{35}$

Third, the anti-nuclear movement pushed figures such as Mary Kaldor to the fore, and encouraged others to study defence policy with a critical stance. One idea, for example, was to take advantage of new

\footnotetext{
32 Defence Open Government Document 80/23 of July 1980.

33 On retirement, Quinlan set out his ideas in Quinlan, Michael (2009) Thinking About Nuclear Weapons: Principles, Problems, Prospects, London: Oxford University Press. See also Freedman, Lawrence (2011) 'The Intellectual Legacy of Michael Quinlan', in Bruno Tetrais, Thinking About Strategy: A Tribute to Sir Michael Quinlan, Paris: l'Harmattan.

34 The production team was remarkable for its talent, including Peter Mandelson and David Aaronovitch.

35 Oddly, one of the motivations for a move into undergraduate teaching was a concern that interest in the MA might drop off with the end of the Cold War.
} 
technologies to avoid any appearance of having an offensive capability, while making it extremely hard for a would-be attacker to invade so called 'non-offensive defence'. ${ }^{36}$ In addition, a very different sort of critical security studies began to develop, in some ways akin to the one that had developed in the 1960s around the Vietnam War, as those opposed to the war questioned how society had become so warlike and whose interests were served by the constant resort to military means. This turned into a more general critique of the Western political order. The difference now was the stress on issues of gender and race as factors which shaped power structures. ${ }^{37}$

One example of this shift was Ken Booth, who had become an increasingly critical voice within the mainstream, but then began to take an increasingly radical stance. ${ }^{38}$ Booth was at Aberystwyth, which became the centre of critical security studies in the UK. ${ }^{39}$ Whereas a previous Head of Department, John Garnett, had praised the virtues of common sense and warned against the subject becoming too complex and esoteric, ${ }^{40}$ now postmodernism was used to question Western habits of thought, stressing the emancipatory potential of international relations in contrast to supporting the status quo. ${ }^{41}$ One of the challenges for this way of thinking was that it was removed from the main political parties in its language and concepts. In its most Foucault-driven manifestations, it was not always expressed in

36 See Barnaby, Frank and Egbert Bouker (1982) Defence Without Offence: Non-nuclear Defence for Europe, Peace Studies Paper No. 8, Bradford University; The Alternative Defence Commission (1983) Defence without the Bomb: The Report of the Alternative Defence Commission, London: Taylor and Francis.

37 On the changing character of security studies, see Buzan, Barry and Lene Hansen (2009), The Evolution Of International Security Studies, Cambridge: Cambridge University Press. Buzan has been an innovative figure in international relations who also contributed to strategic studies. See Buzan, Barry (1987) An Introduction To Strategic Studies: Military Technology And International Relations, London: Macmillan.

38 Booth, Ken (1991) 'Security in Anarchy: Utopian Realism in Theory and Practice', International Affairs 67(3), pp. 527-45.

39 For a while, a Welsh School was identified as distinct from an English School, until Booth decided there was nothing particularly Welsh about it.

40 Garnett, John (1984) Commonsense and the Theory of International Relations, London: Macmillan.

41 Richard Wyn Jones became a leading exponent of the Welsh School. See Jones, Richard Wyn (1999) Security, Strategy and Critical Theory, Colorado: Lynne Rienner. 
a form that was intelligible to a lay audience. ${ }^{42}$ With the growth of the universities came new forms of funding, and publications became a key indicator of value, whether or not they were actually read. If anything, the study of international relations became progressively detached from its practice.

The most important shift was in the nature of international relations. After the alarm that accompanied what Fred Halliday called the Second Cold War in the early $1980 \mathrm{~s}^{43}$ came the second shock of the complete end of the Cold War. Whatever may be said about the prescience of Western scholars in anticipating this development, there is an important story in the role of British academics in helping it along. As already noted, one role played by Chatham House and other think tanks was in keeping open some sort of dialogue with the Soviet bloc. ${ }^{44}$ This was done through the regular round tables organised by Chatham House (the first of which had met in 1975), or the form of informal diplomacy practiced by John Erickson, who arranged meetings with Soviet figures in Edinburgh. ${ }^{45}$ Some of this was done in response to what was seen as an overly hawkish attitude taken by Prime Minister Margaret Thatcher. Yet Thatcher held a number of day-long seminars with academics at Chequers on security issues and took note of what they said. It was at one of these seminars that Archie Brown of Oxford University expressed the view that change was coming in the Soviet Union, and that Britain should seek to cultivate the next generation. As a result of this, Mikhail Gorbachev was invited to London even before he had taken power in Moscow. At an extraordinary small meeting with specialists in the Soviet economy and arms control, Thatcher was fully briefed on the challenges that Gorbachev would

42 For a critique of this trend, see Wallace, William (1996) 'Review: Truth and Power, Monks and Technocrats: Theory and Practice in International Relations', Review of International Studies 22(3), pp. 301-21. Wallace warned against self-indulgence, detachment from political life, and refuge in abstractions, theories, and meta-theories. This prompted a lively debate, with key figures from Aberystwyth, such as Ken Booth and Steve Smith, arguing for a wider view of politics, focused more on civil society.

43 Halliday, Fred (1983) The Making of the Second Cold War, London: Verso.

44 See Pravda, Alex and Peter Duncan (1970) Soviet-British Relations since the 1970s, Cambridge: Cambridge University Press.

45 The Guardian (2002) 'Humanities: John Erickson'. Available at: www.theguardian.com/ news/2002/feb/12/guardianobituaries.humanities. 
face and the value of establishing a constructive relationship with him. The meeting with Gorbachev ended with Thatcher's famous proclamation that here was a man with whom she could do business. ${ }^{46}$

While it was hard to complain about the end of the Cold War, as the world suddenly seemed a safer place, there was an abrupt obsolescence of expertise. Hard-earned knowledge on verification and arms control, first strikes, and NATO doctrine appeared irrelevant. Then suddenly new types of expertise were required as Saddam Hussein invaded Kuwait, followed by its liberation by an American-led coalition, and then the Soviet Union and Yugoslavia fell apart. In addition to a grasp of actual military operations, rather than hypothetical nuclear exchanges, it was now necessary to have an understanding of regional conflicts, or how weak states could fall apart under pressure. The new issues involved questions of intervention in internal conflicts and then, later, the challenges of terrorism.

In some ways, the universities found it easier to respond to these challenges than the think tanks. This was partly because they were growing as the cold War came to an end, but also because new disciplines - such as sociology and anthropology - were now needed to deal with the new types of conflict in which ethnicity seemed to play a prominent role, and knowledge of areas such as the Middle East and the Balkans was required. Although the think tanks soon caught up, and were able to use their international networks to develop the necessary links with post-communist Europe, at first the necessary expertise tended to be more at hand in the universities, where there was also a supply of research students and post-doctorates who began to take on the weight of hard research. In addition, university-based academics, including Bob O'Neill, once at Oxford, engaged directly with a new generation of curious students, including young officers at the staff colleges.

46 See Brown, Archie (2008) 'The Change to Engagement in Britain's Cold War Policy: The Origins of the Thatcher-Gorbachev Relationship', Journal of Cold War Studies 10(3). The episode is described also in Moore, Charles (2015) Margaret Thatcher: The Authorized Biography, Vol. II: Everything She Wants, London: Allen Lane, pp. 231-2. I was there, but played a minor role. My main recollection was that, at the end of the meeting, after formidable briefings by Brown, Alec Nove, and Michael Kaser on the travails of the Soviet Union, to which she listened intently, Thatcher asked if they still believed in 'world domination'. 


\section{V}

This was a time of uncertainty and possibilities. My recollection, especially after 1985, is of a continuing conversation, conducted in the universities and think tanks, together with policy-makers and the media, about a world that was straining to escape from the constraints of the Cold War. The normal charge made against the strategic studies community of this period was that it failed to anticipate the collapse of the Soviet Union. Looking back, I am unconvinced of this. The first half of the 1980s was tough, with an ailing Soviet leadership stubbornly clinging to the old ways, and a hawkish American President who seemed less interested in a comfortable détente than victory in the Cold War. By the second half of the decade, it was evident that something was up, and, as we have seen, the astute Soviet-watchers of the period knew that the current system was untenable and would change when a new leadership took over. How it would change could not be known. It depended on decisions to be made, not least in the Kremlin. By the last years of the 1980s, few doubted that important changes were underway, and much time was spent speculating on how far Gorbachev would dare go in reforming the system.

In addition, security issues in a variety of regions were becoming detached from the East-West confrontation. This had become clear in the Middle East, where Iran and Iraq were at war for most of the decade. A glance at the Adelphi Papers of the 1980s illustrates the shift. In these pre-blogging years, there was a lag from commissioning to publication, which explains the number of papers on ballistic missile defence that came out a few years after Reagan's 'star wars' speech of March 1983. But there were also regular papers on regional changes, from East Asia to the Mediterranean, and two papers on the Iran-Iraq war. The 1988 IISS conference was on changes in the strategic landscape, published as Adelphi Papers the next year.

In practice, by the time the Cold War ended, it was less important for the management of the generality of international problems than it had been when it began. This meant that while the sudden surge of warmth between Moscow and Washington, and London, encouraged talk of a new era of peace, there were many international conflicts that had their own dynamic, independent of the wishes and interests of the great powers. Even in Europe, ideas that the collapse of communism 
WAR, STRATEGY AND HISTORY

could somehow be managed as a sort of controlled explosion, without too much disruption, turned out to be too optimistic. Having lost a form of international order that appeared stable because of the balance of terror, there was a search to describe a new world order that was as stable but based on something more positive than a mutual fear of nuclear war. The search is still on. 
This text is taken from War, Strategy and History: Essays in Honour of Professor Robert O'Neill, edited by Daniel Marston and Tamara Leahy, published 2016 by ANU Press, The Australian National University,

Canberra, Australia. 